ELORE (ISSN 1456-3010), vol. 17 - 2/2010.

Julkaisija: Suomen Kansantietouden Tutkijain Seura ry.

[http://www.elore.fi/arkisto/2_10/lauren_2_10.pdf]

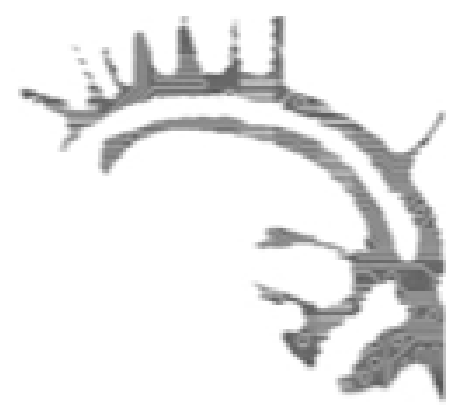

KIRJA-ARVIO

\title{
AMmattinaiset JA -MIEHET METSÄssÄ
}

Suopajärvi, Tiina 2009: Sukupuoli meni metsä̈̈n. Luonnon ja sukupuolen polkuja metsäammattilaisuudessa. Suomalaisen Kirjallisuuden Seuran toimituksia 1255. Helsinki: SKS. 387 sivua.

\section{Kirsi Laurén}

Ammatit ovat edelleen eriytyneet sukupuolen mukaan, eivät ainoastaan muualla maailmassa vaan myös tasa-arvoiseksi maailmankolkaksi mielletyssä pohjoisessa. Sitä on vaikea kiistää, vaikka haluaisikin. Tasa-arvo ja sukupuoli liittyvät myös ympäristökysymyksiin. Sukupuolen esiin nostaminen ja sen merkitysten tutkiminen ympäristökysymyksissä paljastaa uudenlaisia, aiemmin huomaamattomia näkökulmia (ks. esimerkiksi Alue ja ympäristö 2/2009). Sukupuolella on merkitystä muun muassa metsäalan ammattilaisuudessa, joka kytkeytyy myös ympäristökysymyksiin ja -tutkimukseen. Oulun yliopiston kulttuuriantropologin Tiina Suopajärven väitöstutkimuksessa paneudutaan tuoreella otteella suomalaiseen kulttuuriin ja yhteiskuntaan keskeisesti vaikuttaneeseen metsäalaan ja -ammattilaisuuteen. Pitkästä metsäalan kokemuksestaan, koulutuksestaan ja ammattilaisurastaan huolimatta naiset ovat aivan viime vuosikymmeniin saakka jääneet metsäalalla päärooleissa esiintyneiden miesten varjoon niin ammattikuntansa edustajina kuin tutkimuskohteina. Metsätyömiehiä ja heidän perinteitään on tutkittu (esim. Snellman 1996; Pöysä 1997; Tervo 2008) ja tarkasteltavina ovat olleet myös yliopistokoulutuksen saaneet metsänhoitajanaiset ja -miehet (Kärkkäinen \& Toivanen 1995; Paaskoski 2008). Suopajärven tutkimuksessa rinnakkain näyttämölle astuvat metsäteknikon ja metsätalousinsinöörin koulutuksen saaneet metsätoimihenkilöinä työskentelevät naiset ja miehet.

Tutkimusaineisto koostuu 1991-2002 järjestetyn Metsäammatit metsätalouden murroksessa -tallennushankkeen tuloksena kootuista elämäkerrallisista haastatteluista. Laajassa haastatteluaineistossa riittää tutkittavaa ja sitä onkin jo hyödynnetty eri 
tieteenaloilla niin pienemmissä opinnäytetöissä kuin väitöstutkimuksissa. Tallennushankkeen organisoivat Metsähistorian Seura, Helsingin yliopiston kansatieteen oppiaine ja Suomen Metsämuseo Lusto ja siinä haastateltiin yli tuhatta metsäalan ammattilaista eri puolilla Suomea. Tästä laajasta haastateltavien joukosta Suopajärvi on valinnut omaan tutkimusaineistoonsa sen kaikki 33 haastateltua naispuolista metsätoimihenkilöä sekä yhtä monta saman koulutuksen saanutta miespuolista metsätoimihenkilöä. Tutkimusaineisto käsittää siis yhteensä 66 haastattelua.

Tämän empiirisen, kokemuksia käsittelevän tutkimuksen tavoitteena on ollut tutkia ekofeministisen näkökulman kautta metsäammattilaisuuden, sukupuolen ja luonnon välisiä suhteita. Teoreettiseksi lähtökohdakseen tutkija on valinnut sukupuolen käsitteen ja sen suhteen tilaan, asiantuntijuuteen ja luontosuhteeseen. Näkökulmaa tarkennetaan siihen, millainen yhteys on toisiinsa niillä tavoilla, joilla metsäammattilaiset kertovat sekä sukupuolesta että luonnosta. Samalla tutkija testaa aineistoonsa ekofeminististä näkemystä, jonka mukaan sukupuolella olisi merkitystä luontosuhteeseen. Tämä näkemys noudattelee sosiaalista ekofeminismiä, jonka mukaan sukupuolisidonnainen sosiaalistuminen sitoo sen yhteen sukupuolijärjestelmän mekanismien kanssa. Tutkija analysoi haastateltavien suhdetta luontoon tästä näkökulmasta tarkastelemalla sen ajallista, paikallista ja sosiaalista muotoutumista. Kuten tulkitsevaan analyysiin perustuvaan tutkimukseen kuuluu, tutkija pohtii samalla myös omaa suhdettaan tutkittaviin, tutkittavaan ilmiöön ja omiin tieteellisiin intresseihinsä. Kun tutkimuksen taustat ja vaikuttimet kirjoitetaan avoimesti näkyville - niin kuin ne on tässä tutkimuksessa kirjoitettu - avautuu myös lukijalle tilaisuus tulla tietoiseksi niiden mahdollisesta vaikutuksesta analyysiin ja tutkimustuloksiin.

Suopajärvi tarkastelee aineistoaan sisällönanalyysin keinoin ja kytkee analyysinsa havainnollisesti ja monipuolisesti niihin yhteiskunnallisiin tapahtumiin, joissa haastateltavat ovat eläneet ja joihin heidän kertomuksensa nivoutuvat. Analyysi on kirjoitettu kiinnostavasti ja siitä välittyy tutkijan perusteellinen perehtyminen aineistoonsa ja sen kulttuuriseen, yhteiskunnalliseen ja historialliseen kehyskertomukseen. Vaikka analysoitavana on keskeisesti 66 haastattelua, tutkijalla on käsitys koko haastatteluaineistosta ja sen taustoista. Tutkimusaineisto on kattava ja sitä käsitellään huolellisesti ja sensitiivisesti, jonka johdosta analyysista muodostuu uskottava. Aineistolainaukset ovat informatiivisia ja tutkija on saanut ne hedelmälliseen vuoropuheluun teorian ja tutkimuskirjallisuuden kanssa. Vaikka kirjan alkupuolella käydään läpi haastatteluteemat, olisi haastattelurungon lisääminen liitteisiin kuitenkin avannut tutkimusasetelmaa lukijalle vielä selkeämmin. Se mitä ja miten kysytään, vaikuttaa keskeisesti haastateltavien vastauksiin.

\section{MetsäsuHde JA -AMMATTILAISUUS YHTEENKIETOUTUNEINA}

Elämäkerralliset, eri ajanjaksoissa liikkuvat haastattelut antavat erinomaisen mahdollisuuden kirjoittaa yhteiskunnalliseen ja historialliseen kontekstiinsa kytkeytyvä analyysi. Tähän mahdollisuuteen Tiina Suopajärvi on tarttunut ansiokkaasti. Kirjassa 
Kirsi Laurén: Ammattimiehet ja -naiset metsässä

taustoitetaan mukaansatempaavasti tutkittavien luontosuhdetta ja metsäammattilaisuutta aina lapsuuden metsäkokemuksista lähtien, joiden pariin päästään analyysissa ensimmäiseksi analyysiosan aloittavassa Lapsuuden metsässä -luvussa. Metsäammattilaisuutta oppimassa -luvussa paneudutaan seikkaperäisesti paitsi ammattiasiantuntijuuden rakentumiseen myös suomalaisen keskiasteen metsäkoulutuksen historiaan ja naisten mukaantuloon miehisenä pidetylle koulutusalalle. Kirja tarjoaakin metsäalan koulutuksesta oivallisen tietopaketin, johon tutkimusaineiston kokemuksellinen muistitieto tuo uutta informaatiota. Myös Muuttuva metsäasiantuntijuus ja Sukupuolistunut asiantuntijuus -luvuissa kerrotaan seikkaperäisesti ja pitkällä aikavälillä metsäasiantuntijuudesta ja sen muutoksista alkuajoista nykypäivään. Metsäalalla naiset ovat toimineet osittain totuttujen roolimallien mukaisesti miesten tavoin, mutta he ovat myös olleet luomassa avoimempaa ja ihmisläheisempää toimintakulttuuria. Tutkimuksessa tuodaan myös esille, että metsäalan asiantuntijuuden muuttumisessa kohti sosiaaliseen vuorovaikutukseen pohjautuvaa asiantuntijuutta ovat vaikuttaneet muutkin seikat kuin naisten mukaantulo. Keskeisimpiä muutosten vauhdittajia on ollut muun muassa 1960-luvulta lähtien alkanut ympäristöliikehdinnän radikalisoituminen.

Merkitysten metsässä -luvussa haastateltavien metsälle antamat merkitykset kertovat heidän läheisestä ja konkreettisesta suhteestaan metsään. Vaikka metsä kytkeytyy vahvasti ammattiin ja työhön, suuntaavat niin naiset kuin miehet omaan metsäänsä mielellään myös vapaa-aikanaan. Metsätöiden koetaan tuottavan mielihyvää ja rentoutumisen mahdollisuuksia. Haastateltavat antavat etenkin omalle perintömetsälleen tunnesidonnaisen merkityksen. Tähän vaikuttaa keskeisesti se, että metsällä on ajallista ulottuvuutta aina sukupolvien taakse. Lapsuus ja lapsuuden koti nousevat metsäammattilaisten puheessa merkittäviksi niin oman metsäsuhteen kuin ammatinvalinnan perusteluissa. Metsän merkitys on heille tunteellisesti latautunut ja laaja-alainen, se on "elinympäristö ja elämäntapa", kuten eräs haastateltavista toteaa. Tutkijan mukaan hänen tutkimiensa metsäammattilaisten suhde metsään perustuu kuitenkin lähtökohtaisesti taloudellisille arvoille.

\section{METSÄKULTTUURIN ÄÄRELLÄ}

Suomessa, metsäläisten maassa, metsäteeman ympärillä riittää tutkimusta ja asiantuntijuutta eri aloilta. Monilla on sanottavaa, kun on kyse metsien hoidosta, metsätaloudesta tai metsien käytöstä. Jopa metsäkulttuurin, tuon vakavan tiedon hauskana ja harmittomana elävöittäjänä pitkään pidetyn ulottuvuuden, perään on alettu kysellä eri suunnilta sen jälkeen kun se kansainvälisesti tunnustettiin yhdeksi kestävän kehityksen tärkeäksi osa-alueeksi (Brundtlandin komission raportti 1987). Mutta harvemmalla on käsitystä siitä, mitä kulttuurisella kestävyydellä oikein tarkoitetaan metsien yhteydessä. Usein se sidotaan tai sisällytetään sosiaaliseen kestävyyteen, jonka kanssa sillä onkin paljon päällekkäisyyttä. Tukkilaisromantiikka, tuohikontit ja 
Kirsi Laurén: Ammattimiehet ja -naiset metsässä

kirjallisuudesta tutut metsämiesten runot ja laulut ovat helpommin haltuun otettavia, selkeästi menneisyyteen kuuluvaa kulttuuria, joka vedetään tyypillisesti esiin, kun aletaan puhua metsäkulttuurista. Mutta entäpä nykypäivän metsäkulttuuri, mistä sen voi tavoittaa? Menneisyyden esiin nostaminen yhä uudelleen ei yksinään riitä täyttämään kulttuurisesti kestävän kehityksen tavoitteita metsissä nykypäivänä. Sitä on siis etsittävä jostain muualta. Tiina Suopajärven tutkimus tarjoaa mielestäni yhden valottavan esimerkin nykypäivän metsäkulttuurin ulottuvuuksista etsimällä ja tuomalla esiin sukupuolistuneet tavat toimia ja ajatella metsästä ja metsäammattilaisuudesta. Tämä on yksi selkeä ja merkittävä metsäkulttuurin osa-alue luonnonkäytön kestävää kehitystä pohdittaessa.

Sukupuoli meni metsään on vahva, hyvin kirjoitettu tutkimus, joka piirtää havainnollisen kuvan suomalaisesta metsäammattilaisuudesta ja metsäsuhteen prosessinomaisesta, jatkuvasti liikkeessä olevasta luonteesta. Kirjaan kannattaa tarttua, jos on kiinnostunut luontosuhteen muotoutumisesta, ympäristöstä ja kulttuurista, metsäkulttuurista, metsäammattilaisuudesta, metsähistoriasta, metsänomistajuudesta tai gender-näkökulmista. Uskon, että moni metsäammattilainen, sukupuoleen katsomatta, ottaa myös tämän kirjan mieluusti luettavakseen - suosittelen ainakin.

\section{KirJallisuUs}

Alue ja ympäristö 2/2009. Teemanumero: Arkielämän luontosuhteet ja sukupuoli.

KÄRKKÄINEN, SIRPA \& TOIVANEN, ERJA 1995: Uudistusalalla. Naismetsänhoitajien elämää vuodesta 1918. Helsinki: Naismetsänhoitajat ry.

PÖYSÄ, JYRKI 1997: Jätkän synty. Tutkimus sosiaalisen kategorian muotoutumisesta suomalaisessa kulttuurissa ja itäsuomalaisessa metsätyöperinteessä. Suomalaisen Kirjallisuuden Seuran toimituksia 669. Helsinki: SKS.

SNELLMAN, HANNA 1996: Tukkilaisten tulo ja lähtö. Kansatieteellinen tutkimus Kemijoen metsä- ja uittotöistä. Scripta Historica 25. Oulun Historiaseuran julkaisuja. Oulu: Pohjoinen.

TERVO, KATJA 2008: Metsän hiljaiset. Metsätyön rakennemurrosten kolme sukupolvea. Suomalaisen Kirjallisuuden Seuran toimituksia 1177. Helsinki: SKS.

Filosofian tohtori Kirsi Laurén on perinteentutkija Karjalan tutkimuslaitoksella Itä-Suomen yliopistossa Joensuussa. 